\title{
Photosynthesis Inhibition of Pyrogallol Against the Bloom-Forming Cyanobacterium Microcystis aeruginosa TY001
}

\author{
Jie Wang, Qi Liu, Jia Feng, Junping Lv, Shulian Xie* \\ School of Life Science, Shanxi University, Taiyuan 030006, China
}

Received: 11 April 2016

Accepted: 26 May 2016

\begin{abstract}
Severe eutrophication and harmful cyanobacterial blooms of freshwater ecosystems has been a persistent environmental topic in recent decades. Allelochemical inhibition has received great attention in aquatic ecology and quality management. This study investigates the growth and full photosynthesis performance of pyrogallol on Microcystis aeruginosa TY001. The growth and pigment contents of M. aeruginosa were seriously inhibited by pyrogallol. The relative expression levels of the $n b l A$ gene were up-regulated under pyrogallol treatments. Unexpectedly, the relative transcript abundance of the $p s a B$ and $p s b A$ genes significantly increased compared with the control, but the chlorophyll fluorescence parameters of $M$. aeruginosa TY001 decreased significantly, except at $1 \mathrm{mg} \mathrm{L}^{-1}$ pyrogallol. In conclusion, the target sites of pyrogallol's toxic effect on the PSII of M. aeruginosa TY001 were mainly on the active reaction centers and the electron transport at the acceptor side.
\end{abstract}

Keywords: pyrogallol, allelopathic, Microcystis aeruginosa, gene expression, photosystem II

\section{Introduction}

Harmful algae blooms (HABs) have become a widespread concern in recent decades due to their frequent occurrence in eutrophic freshwater ecosystems [1-2]. Cyanobacterial blooms, especially of Microcystis aeruginosa, can cause serious water-quality problems in aquatic environments such as issues of oxygen depletion, aquaculture, drinking water supply, and recreational use [35]. Moreover, toxic secondary metabolites (cyanotoxins) produced by some bloom-forming cyanobacterial species are lethal to aquatic organisms and highly poisonous to people and livestock [6-7]. The Taiyuan

*e-mail: xiesl@sxu.edu.cn region of the Fenhe River is a large park with a theme of "people, city, ecosystem, and culture," which promotes relaxation, vacationing, and sightseeing [8]. In August 2011, the section of Fenhe River in Taiyuan experienced unprecedented HABs dominated by M. aeruginosa TY001 over a large area. From then on, cyanobacterial blooms occurred every year in the river. Therefore, controlling the excessive growth of planktonic phototrophs in aquatic ecosystems has been a hot topic in HAB management.

Biological control agents have recently received considerable attention worldwide [9]. Allelochemicals have been confirmed to have obvious inhibitory effects on algae proliferation [10]. To date, at least 37 allelochemicals have been demonstrated to be highly effective on phytoplankton [11, 12]. Among them, pyrogallol (polyphenol) was confirmed to exhibit one of 
the most intensive inhibitory effects on $M$. aeruginosa [13-14]. Liu et al. [15] demonstrated that the cell density of $M$. aeruginosa only decreased by $1.6 \%$ after a two-day incubation with $4.5 \mathrm{mg} \mathrm{L}^{-1}$ pyrogallol in $\mathrm{BG}_{11}$ medium. $\mathrm{Lu}$ et al. [16] showed that the biomass of $M$. aeruginosa had a slight decrease after 10-day exposure to pyrogallol at a concentration of $1 \mathrm{mg} \mathrm{L}^{-1}$. However, the effects of high concentrations of pyrogallol on phytoplankton especially in the photosynthetic processes - has not been described.

Photosynthesis is one of the most important physiological process of algae cells and is sensitive to allelochemicals [17-18]. In recent years, gene expression analysis has been widely used to evaluate the impacts of allelochemicals on algae in aquatic systems [19-20]. Shao et al. [21] discovered that M. aeruginosa PCC7806 treated with a low concentration of pyrogallol caused a significant increase in the transcription of the $p s b A$ gene, which encodes the D1 protein and is the key to photosystem II (PS II) $[19,22]$. But the photosynthesis of cyanobacteria could not be predicted based on only one gene. Moreover, chlorophyll fluorescence measurements have been proved to be a rapid and reliable means to exhibit changes in photosynthesis of algae under environment stress [2324]. The effects of chlorophyll fluorescence parameters of $M$. aeruginosa treated with pyrogallol have not been adequately studied, despite the fact that these effects can reliably indicate changes in photosynthetic efficiency under environmental stress [25]. Additionally, more genes must be researched to investigate the photosynthesis inhibition effect of pyrogallol on $M$. aeruginosa.

This research was performed to explore the potential targets for toxicity from pyrogallol on the photosynthetic systems of $M$. aeruginosa TY001. We probed the chlorophyll fluorescence parameters to evaluate photosynthetic performance and the photosystem II defense mechanism in M. aeruginosa TY001. Furthermore, two photosynthesis-related genes ( $p s b A$ and $p s a B$ ) and a phycobilisome-related gene ( $n b l A)$ were selected as target markers to participate in stress responses to pyrogallol.

\section{Materials and Methods}

\section{Algal Strain and Cultivation}

M. aeruginosa TY001 was originally isolated by the authors during HAB events from the Taiyuan region of the Fenhe River, Shanxi province, China $\left(37.87^{\circ} \mathrm{N}\right.$ latitude, $112.55^{\circ} \mathrm{E}$ longitude). The cyanobacteria cells were inoculated into sterile flasks with MA liquid medium (pH 8.2) [26]. The Erlenmeyer flasks were cultured in a homeothermic incubator at $25 \pm 1{ }^{\circ} \mathrm{C}$ under the light at a 12:12 light/dark cycle and an intensity of $40 \mu \mathrm{M}$ photons $\mathrm{m}^{-2} \mathrm{~s}^{-1}$ (cool-white fluorescent tube). The flasks were shaken manually twice daily and rearranged randomly to prevent cells adhering to the side wall and uneven growing caused by minor differences in photon irradiance.

\section{Exposure to Pyrogallol}

Pyrogallol was purchased from Tianjin Guangfu Fine Chemical Research Institute (Tianjin, China). The stock solutions of pyrogallol were compounded in water prior to use. The algal cells were cultured in 250-mL Erlenmeyer flasks containing $95 \mathrm{~mL}$ of sterile MA liquid medium at an initial $\mathrm{OD}_{680}$ of 0.110 , then $5 \mathrm{~mL}$ pyrogallol was added into the flasks to make the final concentrations of 0 (control), 1 , $5,10,15$, and $20 \mathrm{mg} \mathrm{L}^{-1}$, respectively. Each treatment was performed in triplicate and cultivated as above for $24 \mathrm{~h}$.

\section{Cell Integrity Test}

Cyanobacterial cell viability was assayed using fluorescein diacetate (FDA, Sigma-Aldrich, USA) and propidium iodide (PI, Sigma-Aldrich, USA). Thirty $\mu \mathrm{L}$ M. aeruginosa TY001 were resuspended in $50 \mu \mathrm{L}$ fresh phosphate buffer sodium (PBS, $50 \mathrm{mM}, \mathrm{pH}$ 7.4). For all staining, PI at a final concentration of $30 \mu \mathrm{M} \mathrm{L}^{-1}$ and FDA $\left(2.4 \mu \mathrm{M} \mathrm{L}^{-1}\right)$ for $30 \mathrm{~min}$ at $25^{\circ} \mathrm{C}$ and in darkness. PI can intercalate and stain DNA when the cell membrane is damaged or a cell dies, so PI was a good indicator for the dead or dying cells [27]. Cells with a damaged cell membrane can emit red fluorescence upon excitation stained by PI, whereas cells with an intact cell membrane can emit green fluorescence upon excitation when stained by FDA [28]. Microscopic images were obtained using laser confocal microscopy (Zeiss LSM 880, Germany). Cell membrane integrity was analyzed by flow cytometer (Accuri C6; BD Accuri Cytometers, Ann Arbor, MI, USA). The detailed procedures were described in Xiao et al. [29]. Data were expressed as the percentage of PI-stained cells.

\section{Determination of Cell Density and Chlorophyll a}

Cell density and $\mathrm{OD}_{680}$ are highly correlated [30], and a strong linear correlation $\left(R^{2}>0.99\right)$ between optical density $\left(\mathrm{OD}_{680}\right)$ and algal cell density has been confirmed [31]. Thus, the cell density of $M$. aeruginosa TY001 was determined at $\mathrm{OD}_{680}$ using a spectrophotometer (UV1800, Shimadzu, Japan).

The chlorophyll a contents of $M$. aeruginosa TY001 were determined according to the ethanol extracting method [32]. In brief, $5 \mathrm{~mL}$ of homogenized algal cells were centrifuged at $4,500 \mathrm{rpm}$ for $10 \mathrm{~min}$, and the supernatant was discarded. The cell pellets were then washed with phosphate buffer sodium (PBS, $50 \mathrm{mM}$, $\mathrm{pH}$ 7.4). The pigment was extracted from the suspended solid residue using $5 \mathrm{~mL}$ ethanol $(95 \%)$ at $4^{\circ} \mathrm{C}$ without light for $24 \mathrm{~h}$. The chlorophyll a contents were then determined at 665-nm and 649-nm wavelengths using a spectrophotometer (UV1800, Shimadzu, Japan) with a blank of ethanol (95\%). The chlorophyll a content was calculated as follows [33]: $\mathrm{C}_{\mathrm{Chl-a}}\left(\mathrm{mg} \mathrm{L}^{-1}\right)=\left(13.95 \times \mathrm{OD}_{665}\right)$ $-\left(6.88 \times \mathrm{OD}_{649}\right)$. 
RNA Extraction, Reverse Transcription, and Quantitative Real-Time PCR

After exposure to pyrogallol, the algal cells were harvested by centrifugation at $8,000 \mathrm{rpm}$ for $5 \mathrm{~min}$. Pelleted cells were resuspended in RNAiso Plus reagent, which were quickly frozen in liquid nitrogen for $1 \mathrm{~h}$. Total RNA was extracted with RNAiso Plus (TaKaRa, China) according to the reagent manual and dissolved in RNasefree water. RNA was quantified by a NanoDrop 2000 UVVis Spectrophotometer (Thermo, Waltham, MA, USA). The total RNA was transcribed reversely into cDNA using the PrimeScript RT reagent Kit with gDNA Eraser (TaKaRa, China), following the manufacturer's protocol. To measure the expression levels of mRNA, qRT-PCR was performed with $10 \mu \mathrm{L}$ SYBR Premix Ex Taq (TaKaRa, China), $0.8 \mu \mathrm{L}(10 \mu \mathrm{M})$ forward and reverse primer, $2 \mu \mathrm{L}$ of 20 -fold diluted cDNA, and $6.4 \mu \mathrm{L}$ distilled water using the Applied Biosystems 7300 Real-time PCR System (Applied Biosystems, USA). The cycle parameters consisted of one cycle at $95^{\circ} \mathrm{C}$ for $3 \mathrm{~min}$ and then 40 cycles of $95^{\circ} \mathrm{C}$ for $15 \mathrm{~s}$ and $60^{\circ} \mathrm{C}$ for $40 \mathrm{~s}$. The relevant primers used in the study and three target genes are presented in Table 1. The 16S rRNA was used as a normalized gene. Transcript levels of the target genes from the qRT-PCR were analyzed by comparing the cycle threshold value $(\mathrm{Ct})$ to the reference gene [34]. This formula was determined as follows: $\left.\Delta \Delta \mathrm{Ct}=\left(\mathrm{Ct}_{\text {target gene }}-\mathrm{Ct}_{165 \text { rrm }}\right)\right)_{\text {stress }}-\left(\mathrm{Ct}_{\text {target gene }}-\mathrm{Ct}_{16 \mathrm{~S}}\right.$ $\left.{ }_{r r n}\right)_{\text {control }}$ Three replicates were used for all experiments, and each experiment included two technical replicates. Amplification specificity was tested using the dissociation curve for all samples.

\section{Determination of Polyphasic Fast Fluorescence Induction and JIP-Test Analysis}

To determine polyphasic fast fluorescence induction, chlorophyll fluorescence was measured with a doublemodulation fluorometer FL3500 (PSI, Inc., Brno, Czech Republic). Thylakoid membranes were dark-adapted for $20 \mathrm{~min}$ before each test. The chlorophyll fluorescence measurements were recorded according to Wang et al. [25]. Moreover, the JIP-test was used to identify polyphasic fluorescence transient, and the terms of the

Table 1. Sequences of primer pairs used in real-time PCR.

\begin{tabular}{|c|c|c|}
\hline $\begin{array}{c}\text { Target } \\
\text { gene }\end{array}$ & Primer sequence $\left(5^{\prime}-3^{\prime}\right)$ & Ref. \\
\hline $16 S$ rrn & $\begin{array}{c}\text { F: GGACGGGTGAGTAACGCGTA } \\
\text { R: CCCATTGCGGAAAATTCCCC }\end{array}$ & {$[18]$} \\
\hline$p s b A$ & $\begin{array}{c}\text { FG: } \\
\text { R: GTTGAAARGAAGAAACCTACAAT }\end{array}$ & {$[18]$} \\
\hline$p s a B$ & $\begin{array}{c}\text { F: CGGTGACTGGGGTGTGTATG } \\
\text { R: ACTCGGTTTGGGGATGGA }\end{array}$ & {$[20]$} \\
\hline$n b l A$ & $\begin{array}{c}\text { F: TTTTCTCTGACCATCATTTGTTCG } \\
\text { R: CAGTTCAACATTCGTTCTTTTCAG }\end{array}$ & {$[42]$} \\
\hline
\end{tabular}

O-J-I-P dynamics curves and the parameters calculated from the fluorescence transient are presented in Table S1 [35].

\section{Statistical Analysis}

The data were obtained in triplicate for every treatment. Significant differences were performed using SPSS 13.0. Parametric one-way analysis of variance (ANOVA) was employed to calculate significant differences $(P<0.05)$ among different treatments.

\section{Results}

\section{Effects of Pyrogallol on Cell Viability}

Damaged cell membranes can emit red fluorescence upon excitation stained by PI, whereas cells with an intact cell membrane can emits green fluorescence upon excitation stained by FDA. In Fig. 1b, the proportion of damaged M. aeruginosa TY001 cells was $5.6 \%$ under $5 \mathrm{mg} \mathrm{L}^{-1}$ pyrogallol stress after $24 \mathrm{~h}$. But in Fig. 1c, the proportions were increased $7.8 \%$ under $15 \mathrm{mg} \mathrm{L}^{-1}$ pyrogallol stress compared with $5 \mathrm{mg} \mathrm{L}^{-1}$. There were nearly no dead cells in the control group (Fig. 1a). As shown in Fig. 1d, all the M. aeruginosa TY001 cells emit green fluorescence upon excitation. But in Fig. 1e, the cells were treated with pyrogallol for $24 \mathrm{~h}$ and they emit green and red fluorescence upon excitation.

\section{Effects of Pyrogallol on Cell Density, Chlorophyll a}

The effects of pyrogallol on the cell density of M. aeruginosa TY001 are presented in Fig. 2a. Low concentrations $\left(1 \mathrm{mg} \mathrm{L}^{-1}\right)$ of pyrogallol had almost no inhibitory effect during the exposure period, but a significant decrease was found in a concentrationdependent manner from $5 \mathrm{mg} \mathrm{L}^{-1}$ to $20 \mathrm{mg} \mathrm{L}^{-1}$ of pyrogallol $(p<0.05)$. The chlorophyll a content exhibited a similar trend (Fig. 2b).

\section{Effects of Pyrogallol on the Gene Expression of M. aeruginosa TY001}

The results of the expression the of $p s b A$ (A), $p s a B$ (B), and nblA (C) genes in M. aeruginosa TY001 under pyrogallol stress after $24 \mathrm{~h}$ are summarized in Fig. 3. The effects of the allelochemical on the relative expression level of photosynthesis-related genes of exposure are presented in Figs $3 \mathrm{a}$ and $3 \mathrm{~b}$. The influence of pyrogallol on the expression of $p s b A$ and $p s a B$ were increased significantly $(p<0.05)$, except at $1 \mathrm{mg} \mathrm{L}^{-1}$. After $24 \mathrm{~h}$ of exposure, the relative transcript abundance of the $p s b A$ gene was $1.20,1.47,1.36$, and 1.67 times that of the control at the $5,10,15$, and $20 \mathrm{mg} \mathrm{L}^{-1}$ concentrations, respectively. The relative expression level of $p s b A$ was not significantly affected by pyrogallol at the $1 \mathrm{mg} \mathrm{L}^{-1}$ concentration, and 
Table S1. Explanation of the terms of the O-J-I-P curves and the selected JIP-test parameters.

\begin{tabular}{|c|c|}
\hline $\begin{array}{l}\text { Technical fluorescence parameters } \\
\text { and formula }\end{array}$ & Illustrations \\
\hline$F_{\mathrm{o}}$ & Initial Chl fluorescence $(50 \mu \mathrm{s})$ obtained in dark-adapted samples \\
\hline$F_{\mathrm{J}}$ & Fluorescence intensity at the J-step (at $2 \mathrm{~ms}$ ) \\
\hline$F_{\mathrm{I}}$ & Fluorescence intensity at the I-step (at $30 \mathrm{~ms}$ ) \\
\hline$F \mathrm{~m}$ & Maximal Chl fluorescence measured under saturating illumination \\
\hline$F_{300 \mu \mathrm{s}}$ & $\begin{array}{l}\text { Calculation of the initial slope (Mo) of the relative variable fluorescence kinetics } \\
\text { (at } 300 \mu \mathrm{s} \text { ) }\end{array}$ \\
\hline$F_{\mathrm{V}}=F \mathrm{~m}-F_{\mathrm{o}}$ & Variable fluorescence intensity \\
\hline$F \mathrm{~V} / F \mathrm{~m}=\left(F \mathrm{~m}-F_{\mathrm{o}}\right) / F \mathrm{~m}$ & Potential maximum photosynthetic capacity \\
\hline$V_{\mathrm{J}}=\left(F_{2 \mathrm{~ms}}-F_{\mathrm{o}}\right) /\left(F \mathrm{~m}-F_{\mathrm{o}}\right)$ & $\begin{array}{l}\text { Relative variable fluorescence intensity at the J-step, reflecting the open state of reaction } \\
\text { centers }\end{array}$ \\
\hline$M \mathrm{o}=4\left(F_{300 \mu \mathrm{s}}-F_{\mathrm{o}}\right) /\left(F \mathrm{~m}-F_{\mathrm{o}}\right)$ & $\begin{array}{l}\text { Approximated initial slope of the fluorescence transient, reflecting the maximum speed } \\
\qquad \text { of } \mathrm{Q}_{\mathrm{A}}^{-} \text {reduction }\end{array}$ \\
\hline & Quantum efficiencies or flux ratios \\
\hline$\psi_{o}=E T_{o} / T R_{o}=1-V_{J}$ & $\begin{array}{l}\text { Probability that a trapped excition moves an electron into the electron transport chain } \\
\qquad \text { beyond } \mathrm{Q}_{\mathrm{A}}^{-}(\text {at } t=0)\end{array}$ \\
\hline$\varphi_{\mathrm{Eo}}=\left[1-\left(F_{\mathrm{o}} / F \mathrm{~m}\right)\right] \psi_{\mathrm{o}}$ & Quantum yield for electron transport (at $t=0$ ) \\
\hline$\varphi_{\mathrm{Po}_{\mathrm{o}}}=\mathrm{TR}_{\mathrm{o}} / \mathrm{ABS}=F \mathrm{~V} / F \mathrm{~m}$ & Maximum quantum yield for primary photochemistry (at $t=0$ ) \\
\hline$\varphi_{\mathrm{Do}}=1-\varphi_{\mathrm{Po}}$ & Quantum yield for dissipation (at $t=0$ ) \\
\hline & Specific fluxes or specific activities \\
\hline $\mathrm{ABS} / \mathrm{RC}=M \mathrm{o}\left(1 / V_{\mathrm{J}}\right)\left(1 / \varphi_{\mathrm{Po}}\right)$ & Absorption flux per reaction center \\
\hline $\mathrm{TR}_{\mathrm{o}} / \mathrm{RC}=M \mathrm{o}\left(1 / V_{\mathrm{J}}\right)$ & Trapped energy flux per reaction center (at $t=0$ ) \\
\hline $\mathrm{ET}_{\mathrm{o}} / \mathrm{RC}=M \mathrm{o}\left(1 / V_{\mathrm{J}}\right) \psi_{\mathrm{o}}$ & Electron transport flux per reaction center (at $t=0$ ) \\
\hline $\mathrm{DI}_{\mathrm{o}} / \mathrm{RC}=\mathrm{ABS} / \mathrm{RC}-\mathrm{TR}_{\mathrm{o}} / \mathrm{RC}$ & Dissipated energy flux per reaction center (at $t=0$ ) \\
\hline$R C / A B S=(1 / M o) \cdot \varphi_{\mathrm{Po}} \cdot V_{\mathrm{J}}$ & Density of RCs based on absorbed energy \\
\hline \multicolumn{2}{|c|}{ Phenomenological energy fluxes(per excited cross section) } \\
\hline $\mathrm{ABS} / \mathrm{CS}_{\mathrm{o}} \approx F_{\mathrm{o}}$ & Absorption flux per cross section (CS) (at $t=0)$ \\
\hline \multicolumn{2}{|r|}{ Density of reaction centers } \\
\hline $\mathrm{RC} / \mathrm{CS}_{\mathrm{o}}=\varphi_{\mathrm{Po}_{\mathrm{o}}}\left(V_{\mathrm{J}} / M o\right)\left(\mathrm{ABS} / \mathrm{CS}_{\mathrm{o}}\right)$ & Number of RCs per CS, reflecting density of RCs \\
\hline \multicolumn{2}{|r|}{ Performance indexes } \\
\hline $\mathrm{PI}_{\mathrm{ABS}}=(R C / A B S)\left[\varphi_{\mathrm{Po}_{\mathrm{o}}} /\left(1-\varphi_{\mathrm{P}_{\mathrm{o}}}\right)\right]\left[\psi_{\mathrm{o}} /\left(1-\psi_{\mathrm{o}}\right)\right]$ & Performance index on absorption basis \\
\hline $\mathrm{PI}_{\mathrm{CS}}=\left(\mathrm{RC} / \mathrm{CS}_{\mathrm{o}}\right)\left[\varphi_{\mathrm{P}_{\mathrm{o}}} /\left(1-\varphi_{\mathrm{P}_{\mathrm{o}}}\right)\right]\left[\psi_{\mathrm{o}} /\left(1-\psi_{\mathrm{o}}\right)\right]$ & Performance index on cross-section basis (at $t=0$ ) \\
\hline
\end{tabular}

the transcript abundance was close to the control. The relative expression level of $p s a B$ in $M$. aeruginosa TY001 varied significantly in a manner similar to that of the $p s b A$ gene. The $p s a B$ relative transcript abundance was 6.51 , $7.10,4.36$, and 19.95 times that of the control at the 5 , 10,15 , and $20 \mathrm{mg} \mathrm{L}^{-1}$ concentrations, respectively. The $p s a B$ gene was not significantly affected $(p>0.05)$ by $1 \mathrm{mg}$ $\mathrm{L}^{-1}$ of pyrogallol. The relative transcript abundance of the $n b l A$ gene was $11.28,9.64,16.20$, and 27.81 times that of the control at the 5, 10, 15, and $20 \mathrm{mg} \mathrm{L}^{-1}$ concentrations, respectively (Fig. 3c). The expression of $n b l A$ was not significantly affected $(p>0.05)$ by $1 \mathrm{mg} \mathrm{L}^{-1}$ of pyrogallol at $24 \mathrm{~h}$ of exposure, as the relative transcript abundance exhibited only a slight increase compared with the control.

\section{Effect of Pyrogallol on the Fast Fluorescence Rise Transient}

The fast fluorescence kinetic induction curves of $M$. aeruginosa TY001 treated with various concentrations of pyrogallol for $24 \mathrm{~h}$ are presented in Fig. 4, and the fluorescence transient was concentration-dependent except at $1 \mathrm{mg} \mathrm{L}^{-1} . F_{\mathrm{J}}$ and $F_{\mathrm{m}}$ dropped clearly and the J-P phase decreased as the pyrogallol concentration increased, 

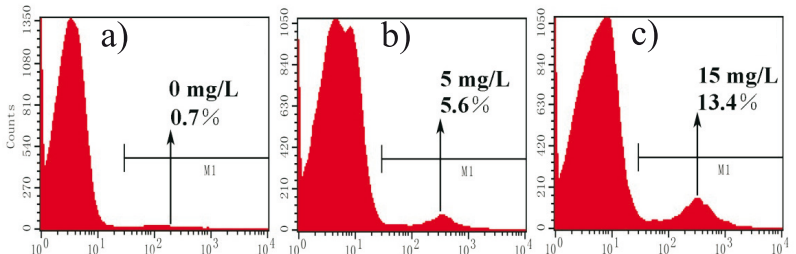

d)

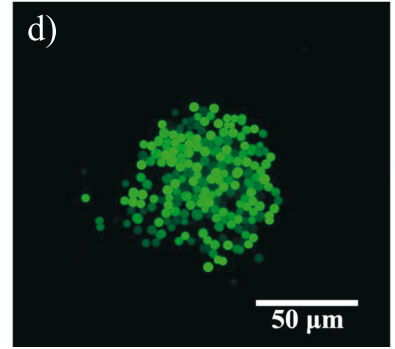

e)

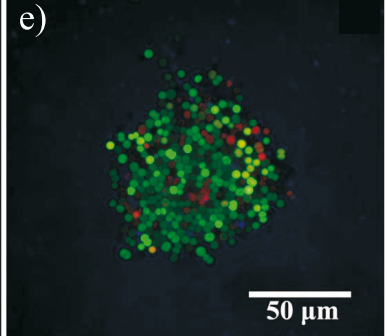

Fig. 1. Flow cytometric histogram of M. aureginosa TY001 stained with PI (M1: the proportion of damaged cells). The proportion of healthy and damaged cells treated with various concentrations of pyrogallol for $24 \mathrm{~h}$ are shown, (a) control group, (b) $5 \mathrm{mg} \mathrm{L}{ }^{-1}$ pyrogallol-treated, and (c) $15 \mathrm{mg} \mathrm{L}^{-1}$ pyrogalloltreated. Fluorescence visualization of viability for $M$. aeruginosa TY001 treated with various concentrations of pyrogallol for 24 h, (d) control group, and (e) treatment group.

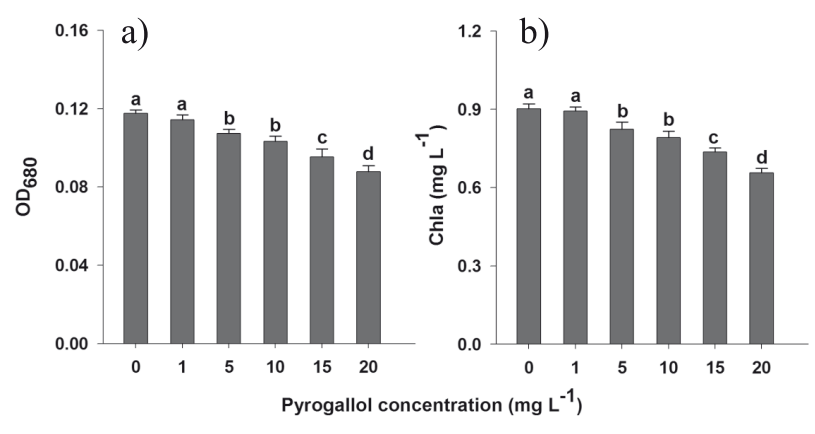

Fig. 2. Cell density $\left(\mathrm{OD}_{680}\right)$ (a) and chlorophyll-a (b) contents of $M$. aeruginosa TY001 treated with various concentrations of pyrogallol for $24 \mathrm{~h}$. Mean values and standard deviation of three replicates are shown. Bars with different alphabet letters indicate significant difference in means among groups with different concentrations $(p<0.05)$.

especially at the 15 and $20 \mathrm{mg} \mathrm{L}^{-1}$ concentrations. Compared with controls, the treated M. aeruginosa TY001 exhibited markedly lower $F_{\mathrm{o}}$ values at concentrations of 5, 10, 15, and $20 \mathrm{mg} \mathrm{L}^{-1}$, but the treated M. aeruginosa TY001 exhibited a higher $F_{\mathrm{o}}$ value at concentrations of $1 \mathrm{mg} \mathrm{L}^{-1}$.

More photochemical information from the JIP-test parameters is presented in Fig. 5. The maximum quantum yield of primary photochemistry $(F \mathrm{~V} / F \mathrm{~m}), \psi_{\mathrm{o}}$, the quantum yield of electron transport $\left(\varphi \mathrm{E}_{\mathrm{o}}\right)$, and the number of RCs per $\mathrm{CS}\left(\mathrm{RC} / \mathrm{CS}_{\mathrm{o}}\right), \mathrm{PI}_{\mathrm{CS}}$, and $\mathrm{PI}_{\mathrm{ABS}}$ were significantly decreased by pyrogallol at concentrations of 5, 10, 15, and $20 \mathrm{mg} \mathrm{L}^{-1}$, but no significant change was observed following treatment with $1 \mathrm{mg} \mathrm{L}^{-1}$. Following incubation
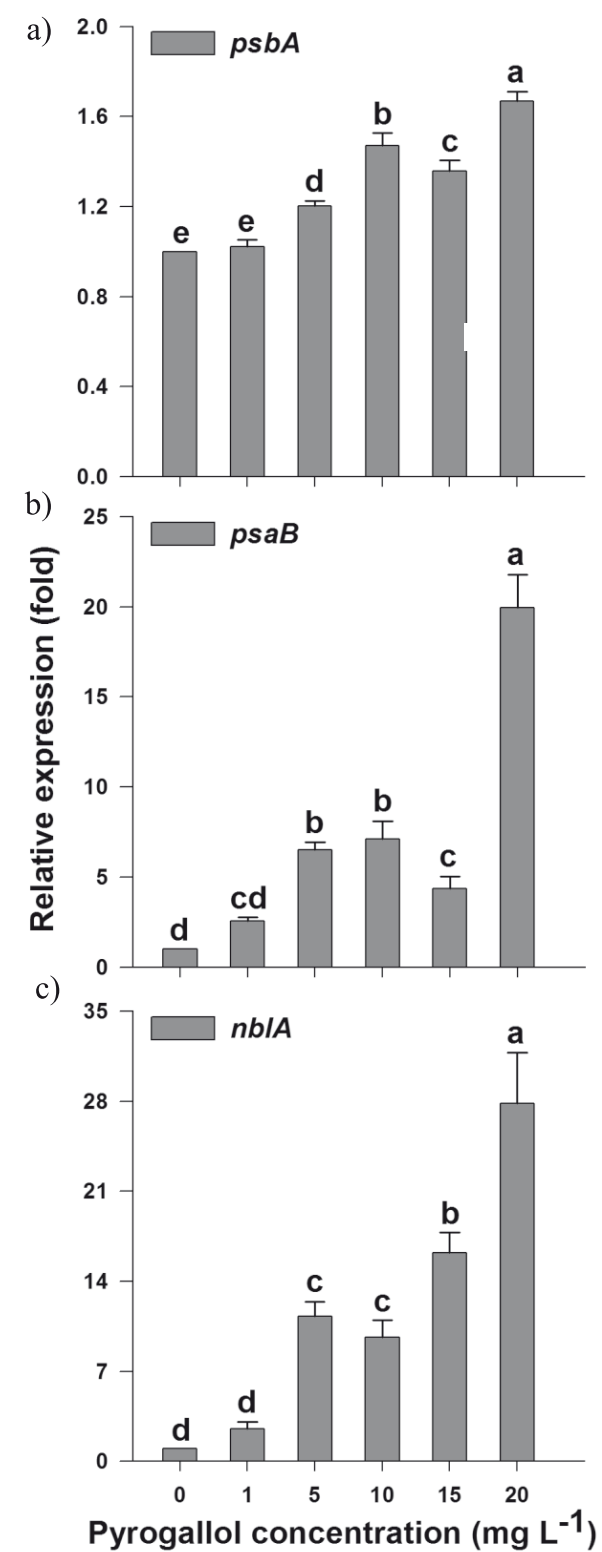

Fig. 3. Effects of pyrogallol on $p s b A$ (a), $p s a B$ (b), and $n b l A$ (c) genes of M. aeruginosa TY001. Mean values and standard deviation of three replicates are shown. Bars with different alphabet letters indicate significant difference in means among groups with different concentrations $(p<0.05)$.

with 5, 10, 15, and $20 \mathrm{mg} \mathrm{L}^{-1}$ pyrogallol, ABS/RC and $\mathrm{DI}_{\mathrm{o}} / \mathrm{RC}$ exhibited remarkable increases compared with the control, but $\mathrm{TR}_{\mathrm{o}} / \mathrm{RC}$ and $\mathrm{ET}_{\mathrm{o}} / \mathrm{RC}$ decreased drastically. Compared with the control, the $\mathrm{M}_{\mathrm{o}}$ were significantly increased following treatment with $5,10,15$, and $20 \mathrm{mg}$ $\mathrm{L}^{-1}$ pyrogallol, and no significant difference was observed at concentrations of $1 \mathrm{mg} \mathrm{L}^{-1}$.

\section{Discussion of Results}

Cyanobacterial blooms cause serious water-quality problems and are becoming a widespread concern in freshwater ecosystems. One current potential and effective 


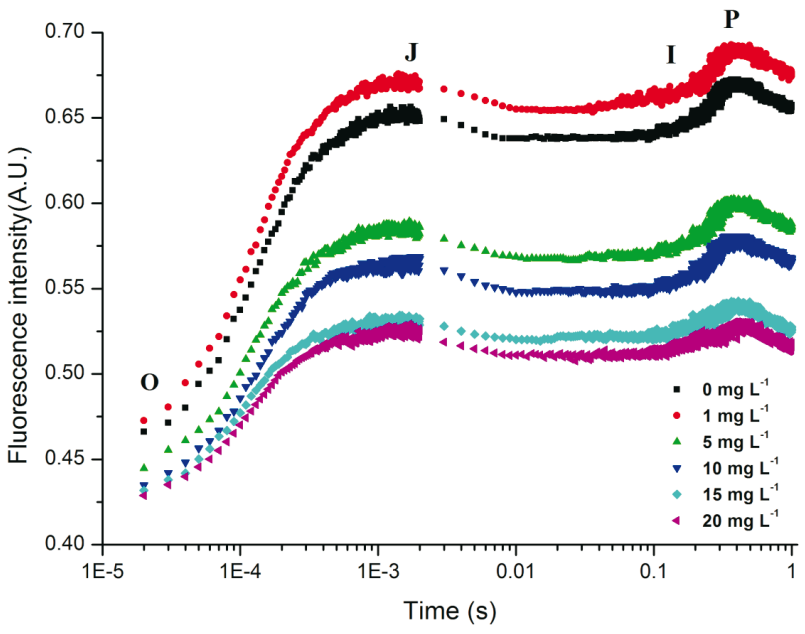

Fig. 4. The fast fluorescence transient of M. aeruginosa TY001 treated with various concentrations of pyrogallol for $24 \mathrm{~h}$. Each value represents the mean of three replicates.

method to inhibit the growth of unpleasant algae is the use of allelochemicals released from aquatic macrophytes [36]. Allelochemicals extracted from various submerged and emergent plants have been reported to possess certain inhibitory effects on target cyanobacteria [37]. Among all chemicals, pyrogallol has been confirmed to exhibit one of the most intensive inhibitory effects on $M$. aeruginosa $[13,38]$. In the present study, the growth of cyanobacteria cells exhibited a positive correlation with the test concentrations of pyrogallol after $24 \mathrm{~h}$ of exposure. This may be because stress exceeded the tolerance limit of M. aeruginosa TY001, causing cell integrity, membrane structure, and photosynthetic capacity to fail. Chlorophylls are the primary algal photosynthetic pigment and play a significant role in light harvesting, light energy transfer,

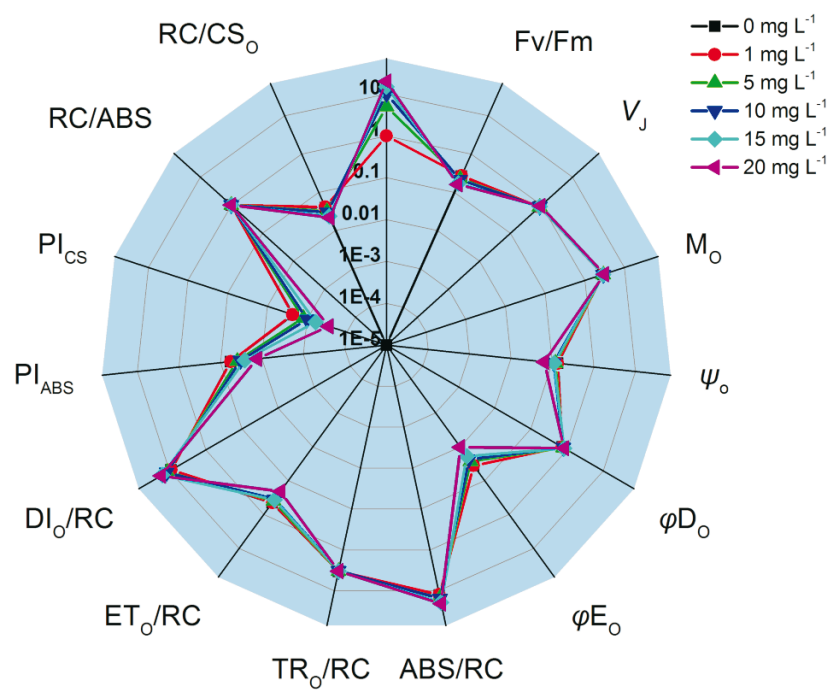

Fig. 5. Radar plot of the JIP-test parameters calculated from the fluorescence transient. Each value represents the mean of three replicates. and conversion during the photosynthesis process [24]. The chlorophyll a content decreased markedly after exposure to pyrogallol, which may be because the stress of the allelochemical decreased the photo-oxidation capacity of $M$. aeruginosa TY001.

Photosynthesis is one of the most significant metabolic activities of cyanobacterial cells. Photosynthesis converts light energy to chemical energy by means of two large protein complexes, photosystems I (PS I) and II (PS II), located in the thylakoid membranes [39, 40]. The gene psaB encodes the P700 chlorophyll a A2 apoproteins, which is one of the essential component of PS I, whereas $p s b A$ encodes the $\mathrm{D} 1$ protein that forms the key reaction center subunits of photosystem II (PS II) [19, 22]. Shao et al. [21] reported that pyrogallol increased $p s b A$ gene expression in $M$. aeruginosa PCC7806. In the present study, the relative expression level of $p s a B$ in the PS I and $p s b A$ in the PS II reaction centers significantly increased compared with the control after exposure to pyrogallol for $24 \mathrm{~h}$. The results indicated that the photosynthetic system of $M$. aeruginosa TY001 had already sensed the environmental stress and needed to generate enough new P700 chlorophyll A2 apoproteins and mature D1 protein to replace the damaged ones, likely explaining the reason for the significant increase of $p s a B$ and $p s b A$ gene expression. The $n b l A$ is a gene encoding the low-molecular-weight phycobilisome degradation protein NblA (non-bleaching A), which is involved in the proteolytic degradation of the key cyanobacteria light-harvesting complex, the phycobilisomes (PBSs), under the stress of nitrogen starvation [41]. Lu et al. [42] demonstrated that medium concentrations of allelochemical Epigallocatechin-3gallate (EGCG) caused a significant increase in the transcription of the $n b l A$ gene of $M$. aeruginosa PCC7806. In the present work, the relative transcript abundance of the nblA gene was shown to significantly increase compared with the control, which may induce an added PBS degradation protein and further reduce the efficiency of photosynthesis. Consequently, we deduced that more degradation of PBSs may be another explanation for the photoinhibition of pyrogallol-treated $M$. aeruginosa TY001 cells.

To confirm this speculation, the chlorophyll fluorescence parameters and fluorescence transients in $M$. aeruginosa TY001 were measured. It is well known that the chlorophyll fluorescence parameters can exhibit changes in photosynthesis under environment stress, such as the presence of allelochemicals [18], antibiotics [23], and heavy metals [43]. Measurement of fluorescence transience permits the evaluation of the fluxes of photons, electrons, excitons, and energy in PSII [43]. The fast fluorescence kinetic induction curves of $M$. aeruginosa TY001 treated with various concentrations of pyrogallol for $24 \mathrm{~h}$ is presented in Fig. 4, and the fluorescence transient was concentration-dependent except at $1 \mathrm{mg}$ $\mathrm{L}^{-1}$. The results demonstrated that pyrogallol possibly causes hormesis of cyanobacteria. $F_{\mathrm{J}}$ and $F_{\mathrm{m}}$ significantly decreased, and the J-P phase decreased as the pyrogallol concentration increased, illustrating that the electron 
transfer at the donor side of PSII was injured, resulting in the accumulation of $\mathrm{P} 680^{+}$[44]. The decrease of $F_{0}$ with increasing pyrogallol concentration indicates that more fluorescence-quenching centers were present and that the structure of antenna pigments were changed [45-46]. To obtain more important information about the absorption, distribution, and utilization of energy in the photosynthesis of $M$. aeruginosa TY001 after exposure to pyrogallol for $24 \mathrm{~h}$, the JIP-test of the chlorophyll fluorescence transience was performed. In this work, the significant decreases in the $\varphi$ Eo and $\Psi_{\mathrm{o}}$ indicate that the electron transport chain was more vulnerable to the stress of pyrogallol. Moreover, the increase of $V_{\mathrm{J}}$ suggested that the proportion of closed PSII RCs and reduced QA at J step were enhanced. In this study, the ABS/RC was increased significantly, which caused drastic increases in the DIo/RC and $\varphi$ Do. These findings suggest that the number of lightharvesting complexes (LHCs) per RC or the inactivation of some RCs may have been increased [47]. Furthermore, the density of RC/CSo was clearly decreased, which further suggests that inactivation of the reaction centers $(\mathrm{RCs})$ resulted in the increase of $\mathrm{ABS} / \mathrm{RC}$, indicating that pyrogallol damaged the RCs in $M$. aeruginosa TY001. Although pyrogallol induced an increase in the $\varphi$ Do, non-photochemical de-excitation of excited energy can produce ROS [18]. This finding illustrates that the oxidative stress of $M$. aeruginosa TY001 was induced not only from the photo-oxidation of pyrogallol but also from the non-photochemical de-excitation of excited energy in the photosystem itself.

These results, together with data on the chlorophyll fluorescence parameters and fluorescence transients, indicate that membrane disruption leads to photoinhibition and eventually results in the increasing proportion of dead cells as treated with higher concentrations of pyrogallol.

\section{Conclusions}

Our results indicate that pyrogallol, like other allelochemicals, has a significant impact on photosynthesis in $M$. aeruginosa TY001. First, the expression of the nblA gene was up-regulated, which may induce an added PBS degradation protein and further reduce the efficiency of photosynthesis. Second, the chlorophyll fluorescence parameters $\left(F \mathrm{~V} / F \mathrm{~m}, \mathrm{PI}_{\mathrm{ABS}}\right.$, $\mathrm{PI}_{\mathrm{CS}}$ ) of $M$. aeruginosa TY001 decreased significantly, except at $1 \mathrm{mg} \mathrm{L}^{-1}$ pyrogallol, which indicated that the full photosynthesis performance of cyanobacteria was markedly inhibited. These data suggest that photosynthesis inhibition may be an important mechanism by which pyrogallol acts on $M$. aeruginosa TY001. In summary, the high concentration of pyrogallol inhibited $M$. aeruginosa TY001 to the zero or negative growth state after $24 \mathrm{~h}$ of exposure. Further investigation is warranted to determine more inhibitory mechanisms of algae in greater detail to mitigate or eliminate harmful algal blooms in the Taiyuan region of the Fenhe River.

\section{Acknowledgements}

We are grateful to Dr. Erin M. (AJE) for editorial assistance with English. We thank Dr. Yaoming Liu and Le Chen for valuable help in laboratory and in statistical analysis. Our work was supported by the Foundation of the Platform Construction Project of Infrastructure for Science and Technology of Shanxi (No. 20150910040102 to Shulian Xie).

\section{References}

1. PAERL H.W., HUISMAN J. Climate change: a catalyst for global expansion of harmful cyanobacterial blooms. Environ. Microbiol. Rep. 1 (1), 27, 2009.1.

2. MA H.Y., WU Y.L., GAN N.Q., ZHENG L.L., LI T.L., SONG L.R. Growth inhibitory effect of microcystis on Aphanizomenon flos-aquae isolated from cyanobacteria bloom in Lake Dianchi, China. Harmful Algae. 42, 43, 2015.

3. CARMICHAEL W.W. Toxic Microcystis in the environment. In: WATANABE M.F., HARADA K., CARMICHAEL W.W., FUJIKI H., editors, Toxic Microcystis. New York: CRC Press 1, 1995.

4. DODDS W.K., BOUSKA W.W., EITZMANN J.L., PILGER T.J., PITTS K.L., RILEY A.J., SCHLOESSER J.T., THORNBRUGH D.J. Eutrophication of U.S. freshwaters: analysis of potential economic damages. Environ. Sci. Technol. 43 (1), 12, 2009.

5. QIN B.Q., ZHU G.W., GAO G., ZHANG Y.L., LI W., PAERL H.W., CARMICHAEL W.W. A drinking water crisis in Lake Taihu, China: linkage to climatic variability and lake management. Environ. Manage. 45 (1), 105, 2010.

6. KUNIYOSHI T.M., SEVILLA E., BES M.T., FILLAT M.F., PELEATO M.L. Phosphate deficiency (N/P 40:1) induces $m c y D$ transcription and microcystin synthesis in Microcystis aeruginosa PCC7806. Plant Physiol. Biochem. 65 (6) 120, 2013.

7. LIU Y., WANG F., CHEN X., ZHANG J., GAO B.Y. Influence of coexisting spiramycin contaminant on the harm of Microcystis aeruginosa at different nitrogen levels. J. Hazard. Mater. 285, 517, 2015.

8. WANG J., FENG J., XIE S.L., ZHANG J.M., CHENG G., LIAN Y.J. Phytoplankton diversity and off-flavor-producing Microcystis in the Taiyuan region of the Fenhe River. Acta Ecol. Sin. 35 (10), 3357, 2015.

9. KÖRNER S., NICKLISCH A. Allelopathic growth inhibition of selected phytoplankton species by submerged macrophytes. J. Phycol. 38 (5), 862, 2002.

10. BERGER J., SCHAGERL M. Allelopathic activity of Characeae. Biologia. 59 (1), 9, 2004.

11. DONK E.V., BUND W.J.V.D. Impact of submerged macrophytes including charophytes on phyto- and zooplankton communities: Allelopathy versus other mechanisms. Aquat. Bot. 72 (3-4), 261, 2002.

12. GROSS E.M. Allelopathy of aquatic autotrophs. Crit. Rev. Plant Sci. 22 (3), 313, 2003.

13. NAKAI S., INOUE T., HOSOMI M., MURAKAMI A., Myriophyllum spicatum released allelopathic polyphenols inhibiting growth of blue-green algae Microcystis aeruginosa. Water Res. 34 (11), 3026, 2000.

14. DZIGA D., SUDA M., BIALCZYK J., URSZULA C.P., LECHOWSKI Z. The alteration of Microcystis aeruginosa biomass and dissolved microcystin-LR concentration 
following exposure to plant-producing phenols. Environ. Toxicol, 22 (4), 341, 2007.

15. LIU, B.Y., JIANG, P., ZHOU, A.E., TIAN, J.R., JIANG, S.Y. Effect of pyrogallol on the growth and pigment content of cyanobacteria-blooming toxic and nontoxic Microcystis aeruginosa. B. Environ. Contam. Tox. 78 (78), 499, 2007.

16. LU, Z.Y., LIU, B.Y., HE, Y., CHEN, Z.L., ZHOU, Q.H., WU, Z. B. Effects of daily exposure of cyanobacterium and chlorophyte to low-doses of pyrogallol. Allelopathy J. 34 (2), 195, 2014

17. MA, J.Y., WANG, S.F., WANG, P.W., MA, L.J., CHEN, X.L., XU, R.F. Toxicity assessment of 40 herbicides to the green alga Raphidocelis subcapitata. Ecotox. Environ. Safe. 63 (3), 456, 2006.

18. SHAO J.H., LIU D.M., GONG D.X., ZENG Q.R., YAN Z.Y., GU J.D. Inhibitory effects of sanguinarine against the cyanobacterium Microcystis aeruginosa NIES-843 and possible mechanisms of action. Aquat. Toxicol. 142-143 (20), 257, 2013.

19. QIAN H.F., LI J., PAN X.J., SUN Z., YE C., JIN G., FU Z. Effects of streptomycin on growth of algae Chlorella vulgaris and Microcystis aeruginosa. Environ. Toxicol. 27 (4), 229, 2012

20. ZHANG C., LING F., YI Y.L., ZHANG H.Y., WANG G.X. Algicidal activity and potential mechanisms of ginkgolic acids isolated from Ginkgo biloba exocarp on Microcystis aeruginosa. J. Appl. Phycol. 26 (1), 323, 2014.

21. SHAO J.H., WU Z.X., YU G.L., PENG X., LI, R.H. Allelopathic mechanism of pyrogallol to Microcystis aeruginosa PCC7806 (Cyanobacteria): from views of gene expression and antioxidant system. Chemosphere. 75 (7), 924, 2009.

22. NIXON P.J., RÖGNER M., DINER B.A. Expression of a higher plant $p s b A$ gene in Synechocystis 6803 yields a functional hybrid photosystem II reaction center complex. Plant Cell. 3 (4), 383, 1991

23. PAN X.L., ZHANG D.Y., CHEN X., MU G.J., LI L.H., BAO A.M. Effects of levofloxacin hydrochloride on photosystem II activity and heterogeneity of Synechocystis sp. Chemosphere. 77 (3), 413, 2009.

24. WANG S.Z., CHEN F.L., MU S.Y., ZHANG D.Y., PAN X.L., LEE D.J. Simultaneous analysis of photosystem responses of Microcystis aeruginoga under chromium stress. Ecotox. Environ. Safe. 88 (7), 163, 2013.

25. WANG S.Z., ZHANG D.Y., PAN X.L. Effects of arsenic on growth and photosystem II (PS II) activity of Microcystis aeruginosa. Ecotox. Environ. Safe. 84 (7), 104, 2012.

26. KASAI F., KAWACHI M., ERATA M., WATANABE M.M. NIES-Collection, List of Strains, $7^{\text {th }}$ ed. Japan: National Institute for Environmental Studies 257, 2004.

27. ORMEROD M.G. Analysis of DNA. General methods. In: ORMEROD M.G., editors, Flow Cytometry. A Practical Approach. Oxford University Press 69, 1990.

28. KOVÁČIK J., BABULAP., HEDBAVNY J., KRYŠTOFOVA O., PROVAZNIK I. Physiology and methodology of chromium toxicity using alga Scenedesmus quadricauda as model object. Chemosphere. 120, 23, 2015.

29. XIAO X, HAN Z.Y., CHEN Y.X., LIANG X.Q., LI H, QIAN Y.C. Optimization of FDA-PI method using flow cytometry to measure metabolic activity of the cyanobacteria, Microcystis aeruginosa. Phys Chem Earth 36, 424, 2011.

30. KASAI F., TAKAMURA N., HATAKEYAMA S. Effects of smetryne on growth of various freshwater algal taxa. Environ. Pollut. 79 (1), 77, 1993
31. GE F., XU Y., ZHU R.L., YU F.Q., ZHU M.J., WONG M.H. Joint action of binary mixtures of cetyltrimethyl ammonium chloride and aromatic hydrocarbons on Chlorella vulgaris. Ecotox. Environ. Safe. 73 (7), 1689, 2010.

32. EULLAFFROY P., VERNET G. The F684/F735 chlorophyll fluorescence ratio: a potential tool for rapid detection and determination of herbicide phytotoxicity in algae. Water Res. 37 (9), 1983, 2003.

33. LICHTENTHALER H.K., WELLBURN A.R. Determinations of total carotenoids and chlorophylls a and b of leaf extracts in different solvents. Biochem. Soc. T. 11, 591,1983

34. LIVAK K.J., SCHMITTGEN T.D. Analysis of relative gene expression data using real-time quantitative PCR and the 2- $\Delta \Delta C T$ method. Methods. 25 (4), 402, 2001.

35. SIRASSER R.J., SRIVASTAVA A., GOVINDJEE. Polyphasic chlorophyll a fluorescence transient in plant and cyanobacteria. Photochem. Photobiol. 61 (1), 32, 1995.

36. GROSS E.M., GENE E.L. Allelochemical reactions. In: LIKENS G.E., editors, Encyclopedia of Inland Waters. Oxford Academic 715, 2009.

37. BAUER N., BLASCHKE U., BEUTLER E., GROSS E.M., JENETT-SIEMS K., SIEMS K., HILT S. Seasonal and interannual dynamics of polyphenols in Myriophyllum verticillatum and their allelopathic activity on Anabaena variabilis. Aquat. Bot. 91 (2), 110, 2009.

38. NI L.X., ACHARYA K., HAO X.Y., LI S.Y. Isolation and identification of an anti-algal compound from Artemisia аппиа and mechanisms of inhibitory effect on algae. Chemosphere. 88 (9), 1051, 2012.

39. BI X.D., ZHANG S.L., DAI W., XING K.Z., PANG Y., ZHANG D.J. Analysis of effects of berberine on the photosynthesis of Microcystis aeruginosa at gene transcriptional level. Clean- Soil Air Water. 43 (1) 44, 2014.

40. WAN J.J., GUO P.Y., PENG X.F., WEN K.Q. Effect of erythromycin exposure on the growth, antioxidant system and photosynthesis of Microcystis flos-aquae. J. Hazard. Mater. 283, 778, 2015.

41. LUQUE I., ZABULON G., CONTRERAS A., HOUMARD J. Convergence of two global transcriptional regulators on nitrogen induction of the stress-acclimation gene $n b l A$ in the cyanobacterium Synechococcus sp. PCC 7942. Mol. Microbiol. 41 (4), 937, 2001.

42. LU Y.P., WANG J., YU Y., SHI L.M., KONG F.X. Changes in the physiology and gene expression of Microcystis aeruginosa under EGCG stress. Chemosphere. 117 (1), 164, 2014.

43. APPENTOTH K.J., STÖCKEL J., SRIVASTAVA A. STRASSER R.J. Multiple effects of chromate on the photosynthetic apparatus of Spirodela polyrhiza as probed by OJIP chlorophyll a fluorescence measurements. Environ. Pollut. 115 (1), 49, 2001.

44. GOVINDJE E. Sixty-three years since Kautsky: chlorophyll a fluorescence. Aust. J. Plant Physiol. 22 (2), 131, 1995.

45. MURTHY S.D.S., BUKHOV N.G., MOHANTY P. Mercuryinduced alterations of chlorophyll a fluorescence kinetics in cyanobacteria: multiple effects of mercury on electron transport. J. Photochem. Photobiol. B. 6 (4), 373, 1990.

46. PFÜNDEL E.E. Action of UV and visible radiation on chlorophyll fluorescence from dark-adapted grape leaves (Vitis vinifera L.). Photosynth. Res. 75 (1), 29, 2003.

47. EULLAFFROY P., FRANKART C., AZIZ A., COUDERCHET M., BLAISE C. Energy fluxes and driving forces for photosynthesis in Lemna minor exposed to herbicides. Aquat. Bot. 90 (2), 172, 2009. 